\title{
The collapse of the material foundations of Westphalian International Law
}

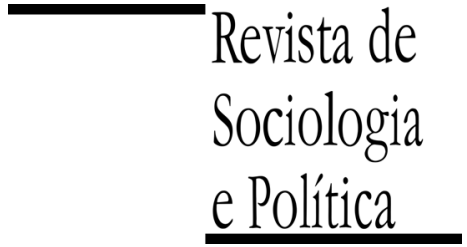

DOI 10.1590/1678-987315235402

\author{
Eugenio Diniz and Domício Proença Júnior
}

\begin{abstract}
This article corresponds to a diagnosis that affirms the collapse of the material foundations of coercive power, the hard constraints of any political direction that seeks to reform of international regulation. It takes the matter within the broad parameters associated with International Law derived from the Treaty of Westphalia, including some of its developments. The evolution of International Law is addressed through the perspective of Strategic Studies to show how the Westphalian order was consistent with then-current underlining strategic, tactical and logistical realities, and then proceeds to demonstrate how those underlining realities have changed. The contrast between current International Law and current strategic, tactical and logistical realities exposes the former as fundamentally at odds, with the latter, which is an untenable situation. Failure to directly address those inconsistencies in an intellectually sustained effort tends to perpetuate a state of affairs in which International Law will be redefined exclusively by the decisions of the powerful and the arbitrary rule of the stronger.
\end{abstract}

KEYWORDS: strategic studies; theory of war; International Law; theory of international relations; current international and strategic state of affairs.

Recebido em 17 de Maio de 2011. Aprovado em 7 de Julho de 2011.

\section{Introduction ${ }^{1}$}

${ }^{1}$ We thank the anonymous reviewers of the Revista de Sociologia e Política for their comments.
$\mathrm{E}$ ffective, useful, and reasonable International Law is essential for regulating trade, exchanges and relationships among governments, organizations, and people. A common assumption of international economic, cultural and social interactions is that International Law can and will account effectively, usefully, reasonably - for the requirements of peace and security.

Yet the whole of current International Law rests upon the Westphalian framework. The realities that led to this framework have been changing since its original conception, in 1648. It proved possible to accommodate successive changes, at a price. The Westphalian framework has been adapted and amended so many times to sustain International Law as changes occurred that it became a patchwork of concessions, exceptions and broad, increasingly twisted interpretations. But the expectation remains that, albeit imperfect, it can endure (e.g., Neff 2005).

That is no longer the case. The Westphalian framework has reached the limit of its ability to cope with change because its material foundations have collapsed. It is time we acknowledge this fact and deal with it.

The current formulations of International Law have reached the limits of their effectiveness and usefulness, thence their continuity as normative guidelines has become unreasonable. Westphalian International Law that has been with us for the past three centuries has lost its ability to serve us in any useful manner. The collapse of its material foundations has turned some of its most cherished precepts into impediments to its essential purpose: meaningful regulation of the relations among sovereign polities. 
The difficulty of Westphalian International Law in dealing with international crime and violence, with the proliferation of weapons of mass destruction, with terrorism and terrorist organizations, with the treatment of detainees in Guantanamo or the situation in Afghanistan, Pakistan, or Iraq are not instances of callous disregard. They are instances that reveal that the logistical, tactical and strategic realities that sustained the framework of expectations, assumptions and norms of Westphalian International Law have changed beyond its ability to deal effectively or usefully with them (cf. Arend \& Beck 1993).

As its core framework has given away, the fabric of International Law is fraying. It is increasingly incapable of addressing the most crucial issue: the regulation of the use of force. We do not yet have anything that will stand in its place. Substantial effort, study, debate, and practice will be needed to rebuild International Law from scratch, because it will be necessary to lay its foundations anew. This reality should be considered in our deliberations and policies, and we must take its consequences into account in our decisions.

This article corresponds to a diagnosis that expresses the collapse of the material foundations of coercive power, the hard constraints of any political direction that seeks to reform of international regulation. It takes the matter within the broad parameters associated with International Law derived from the Treaty of Westphalia, including some of its developments, hence, Westphalian International Law. It emphasizes the perspective of Strategic Studies, addressing the hard aspects of coercive means, the grammar of which corresponds to the conditions of possibility that seek to express the logic of political decisions.

The presentation appreciates, at start, Westphalian International Law (II), which points to the Nature of the Problem (III), followed by a brief historical digression that presents the Challenge of Change (IV), and that punctuates the matter with two additional considerations, those relating to the dynamics of Adapting to Circumstances (V) and dealing with Weapons of Mass Destruction (VI). Theoretical Considerations (VII) offer a capstone through which the previous items can be focused, and which support some concluding remarks concerning Contextual Consequences, towards an agenda (VIII), with an emphasis on the awareness of the problem and the need to address it taking into account the elements previously presented in good time, lest circumstances or a fait accompli settle the matter.

\section{Westphalian International Law}

For the purposes of this text, Westphalian International Law corresponds to a broad and, to some extent, a pragmatic category that expresses the prevalence of Western political and juridical conceptions upon jus gentium, the law of sovereigns (most often States, traditionally, "Nations"), and jus inter gentes, agreements between sovereigns. Part of this prevalence is expressed in its division in terms of Public International Law, Private International Law, and Supranational Law. For the purposes of the discussion, it suffices to understand its reality in terms of jus gentium, although, of course, the matter of the propriety of coercion and compliance can and will influence all other spheres of International Law and of international relations. This corresponds to the terms announced in the introduction as to the potential reach of the issue; but the specific nature or workings of any one interpretation of what would or would not be "Westphalian" (as opposed, for example, to "Islamic") International Law is collateral to the issue: its prevalence, the essential political fact, is taken as a given (e.g., Koskenniemi 2004).

Many authors have discussed the problems, shortcomings, and ineffectiveness of Westphalian International Law. Here we share some that can offer some 
contrast to what we propose, although, as it turns out, none of them were sources for our text - they were found in the tertiary review of the literature, when we sought to place our results in context for publication, and they seem an opportune preamble to what we present.

Anthony C. Arend and Robert J. Beck's International Law and the Use of Force: Beyond the U.N. charter paradigm offers a solid outline of the problem after the end of the Cold War. They characterize an unbroken continuity and the fundamental solidity of the trajectory that leads from Westphalia (1648) to the UN Charter (1945), but acknowledge the reality of the latter's increasingly evident impotence. They conclude that a "paradigmatic shift" is in process and inevitable, and plead for a new convention to found the UN Charter anew. For Arend and Beck, the issue is that the UN Charter, as fashioned in 1945, has outlived its usefulness and should be replaced. While they are despondent before the political difficulty of such an undertaking, they are confident that Westphalian foundations can support a renewed charter to meet present needs satisfactorily.

Stephen C. Neff's War and the Law of Nations proposes that the law has always and thus will always impose itself over the dynamics of war: he presents as evidence an adaptive, unbroken and ever-successful sequence from c. 1600. While he acknowledges that war molds the law and the law molds war, he denies the existence of war as a phenomenon in favor of taking the law as the unifying, and enduring, reality of the matter. He discards any consideration of materiality, logistics, tactics or strategy, and has no room for theory or concepts about war, which he holds to be but ad hoc justifications that match the evolution of the law. So Neff offers almost the exact opposite of the conclusion we offer below, arguing from an equally opposite disciplinary perspective. While he argues that the law will prescribe and regulate the game, defining it regardless of conditions, we argue that the material conditions of war will decide which cards can be played and thus predetermine which games are possible.

H. P. Willmott's When Men lost Faith in Reason offers the refreshing viewpoint of seeing the problem from the point of view of those who have to act. He systematically presents the circumventing of established norms without consequence, the routine disregard for precedent and rule, the overwhelming meaning of nuclear weapons as a potential that would make moot, if not simply churlish, the finer points of propriety and law in lesser circumstances. He commemorates the bold and commiserates the unfortunate few who acted as most others did and yet, due to circumstances, found themselves entangled in the webs of International Law. He argues that much more than International Law failed to endure the stress of the Cold War gracefully - and that all this took place in a war that remained fundamentally cold. Willmott argues that a destruction of values took place in the Cold War and that this suggests nearly insurmountable difficulty of reasserting them, to say nothing of international regulation that would seek to enforce them. The fight against terrorism or the hypocritical, discretionary respect for norms as it suits the case can hardly be taken as ideal circumstances for such an attempt. For Willmott, who does not take International Law as an object but rather as one among many constraints, and who does not seek causes or explanations, but deals with reality as he finds it, aiming at a cogent descriptive narrative, the matter of "International Law" is beyond redemption. For him it is pointless to insist on the value of restraints that do not express immediate, close and firm political goals.

Martti Koskenniemi's The Gentle Civilizer of Nations: the rise and fall of International Law, 1870-1960 emphasizes that Westphalian foundations were taken over, and given their familiar ascendancy, as a result of its political utility in the clash between liberal and authoritarian perspectives, on the one hand; and 
as justification (or condemnation) of particular political agendas in European great power politics and extra-European neocolonialism, on the other. He describes how the pursuit of these divergent agendas produced successive challenges to the validity of the conception, role and prospects of an International Law. While created by the consent of nations, it would henceforth aspire to adjudicate above them. In the 1950s, the enlarged understanding of international relations contextualized by the polar reality of the Cold War reaffirmed the primacy of politics over International Law. For Koskenniemi, this made International Law increasingly alienated from reality, incapable of being more than a rhetorical resource when applied to real issues, and as early as the 1960 s a hostage to the political interests of the great powers - or the lack of it.

As far as we can tell, the proposition that the material aspects of war can be taken as the underlying cause of the limitations of Westhpalian International Law is original. With this preamble we can move on to what we perceive as the nature of the problem.

\section{The nature of the problem}

This is not a problem of International Law, so to say (cf. Koskenniemi 2004). It is an issue that stems from fundamental realities of the use of force: from tactical, strategic, and logistical foundations. It is an issue that goes directly, inexorably, to the assumptions and reasoning that support the very cornerstone of Westphalian International Law. This is a problem with Westphalian International Law. It results from the fact that changes in those foundations have changed beyond the ability of the Westphalian framework that underpins International Law to cope with them. As a result, Westphalian International Law is no longer effective nor useful, and its continuity is therefore unreasonable.

Let us have it very clear, right from the start, that the assumptions of Westphalian International Law accurately reflected the tactical, strategic, and logistical realities of 1648 (Earle 1973; Paret 1986; Delbrück 1990). That is why it was reasonable and able to adapt, for better or for worse, as circumstances changed, making it effective and useful.

In 1648, only kingdoms with the power of central taxation and support of the bourgeoisie could hope to afford guns and gunpowder armies and keep them indefinitely on the field, or ready to take the field: standing armies. Royal armies and guns that tore down feudal castles, controlled the land, overcame all lesser potentates and princes became the mainstay of the modern nation-state. Nation-states which were defined by the reach of those royal armies and guns (Mcneill 1984).

Only kingdoms, in turn, could afford the new, colossally expensive gunproof fortresses. Only the new gun-proof fortresses could stand before the armies and guns of other kingdoms. Soon, the lines of those fortresses marked the borders of those kingdoms. In a little over one hundred years, the feudal era had ended, and the age of princes, of kingdoms, of nation-states, had begun (Gat 2008).

Gunpowder armies and guns were expensive to raise and to keep: they demanded ample funds, scarce resources and particular skills. They required a new kind of discipline and organization. If it only took a few hours to learn how to use a musket - how to load it and fire it - it took years to train troops in the mechanical discipline of the close-order fire drill. Muskets were so inaccurate that only the massed, simultaneous salvo of hundreds could hope to have an effect. The elaborate calculations of the use of gunpowder and guns called for abstract mathematical skills such as trigonometry. The management of these 
armies and guns called for a network of factories, gunpowder mills, and barracks of a professional army. All this called for skills that could only be gained through study: reading, writing, and arithmetic, which were, at first, the privilege of a small elite. Even then, it took decades to make all the weapons an army needed and years to train soldiers to use them in battlefield conditions, to have leaders able to use those weapons and troops in war, and to store the munitions and supplies needed to support armies and guns on campaign, campaigns that could extend in wars eventually lasting years. As a result, fighting became a profession, a profession of arms: exclusive, distinct, and separate from most of the population (Mcneill 1984).

In these circumstances, most of the population had little active role in war. In fact, war was largely confined to the belt of fortresses that dotted the borders between kingdoms. This led to the distinction we take for granted between combatant military and non-combatant civilian, which did not exist until then. So it made sense, in 1648, to establish that only military forces and installations were legal targets in war, and to condemn action against civilians - because civilians were non-combatant and had little if any effect on the outcome of the fighting. This was the underlying tactical, logistical, and strategic basis for the equivalence of civilians and non-combatants. This became part of the framework that reaches the current terms of International Law: at its moment of conception, it was reasonable, useful, and effective (Anderson 1998).

A rising or a revolt of civilians would be very effectively crushed by royal armies and guns. Civilians could not stand in the field with farm tools and hunting pieces against the discipline and firepower of the lines of muskets, the impact and steel of heavy cavalry or pikemen, and the range and power of field-guns. Civilian revolts could not even hope to shelter behind pre-gunpowder city walls that crumbled before royal siege-guns nor hope to overcome the permanently garrisoned modern citadels that held cities hostage to the fire of the King's guns. This was the underlying tactical, logistical, and strategic basis for the monopoly of force of the state in its interior (Mcneill 1984; Gat 2008), thus becoming law: reasonable, useful, and effective.

Only gunpowder armies and guns could hope to lay siege, and take, the new gunpowder fortresses of the other kingdoms. These fortresses were impervious to any of the old techniques. They had troops and guns of their own, that would devastate any non-gunpowder force silly enough to attack them. They had supplies that ensured they would hold, even if surrounded and isolated for a long time - years in fact. Further, they were sited to control the territory and the trade routes, adjoining or, more often, away from the old and largest cities. These locations were well chosen: the control of fortresses was the control of territory, roads and rivers. Only kingdoms could hope to build, hold or take them. Only kingdoms had money, armies, guns, commanders, and supplies for the long months of building, siege or the very rare battle. The most strenuous efforts of non-state actors would produce nothing but waste and suffering, with no prospect of victory. This was the underlying tactical, logistical, and strategic basis for the state's monopoly in war (Alger 1985; Knox \& Murray 2001). And this became law: reasonable, useful and effective.

Ultima ratio regis - the final argument of the king, as it reads on the rim of Louis XIV's cannon. So the Westphalian framework that led to current International Law had everything quite right. It was a valid, effective, and useful norm - it precisely reflected the underlying tactical, logistical, and strategic realities of its time, and sought to regulate the new reality of the state's ascendancy. It did so reasonably, effectively, and usefully because it did not contradict these realities but rather expressed and regulated them. 
IV. The challenge of change

Over three hundred and fifty years have passed. Things have changed. The fundamental reality that underpinned the Westphalian framework and brought about International Law as we know it has ceased to be.

Small arms are cheap, effective and easy to use - a single assault rifle equals the fire of hundreds of muskets with considerably greater range and accuracy. Explosives are powerful, compact, and easy to get and use effectively - a load of RDX or C-4 is more capable than whole batteries of 1648 siege guns. An average person can learn how to use them in hours, how to use them confidently and effectively in combat in a few weeks (Chant 1980; Dunnigan 2003). The knowledge needed to use them for political goals and to sustain them over time is widely available. Our tactical, strategic, and logistical reality is fundamentally different from that of 1648 .

We know this. We have been told of this change systematically throughout these three centuries. We see it everyday. But we have yet to realize where this has brought us, how it has reached a point that is beyond the ability of Westphalian International Law to cope with it.

A century after 1648 it was still possible to preserve what was already turning into a legal fiction, the state's monopoly in war - war in its essence, the act of force to compel others to do our will (Clausewitz 1976), not war as defined in juridical tracts, as the monopoly of princes. But it was possible to persevere with that fiction. The American Revolution of 1776 only succeeded, after all, because other major powers in Europe, notably France, placed Britain in the position of having to fight both the American rebels and a major European power. The revolutionaries had time to come up with armies and guns of their own, but French armies, guns, and ships were indispensable for their victory. Without major power support, the revolutionaries could, as Benjamin Franklin so aptly put it, hang together or separately, but most assuredly hang. Then, in 1789, the French Revolution showed that the support of a major power was not essential for the victory of the revolutionaries. The army itself could change sides; and citizens could now be trained to become soldiers in months, not years. To avoid revolution, armies were insulated from popular passion and kept from political activities after the final defeat of Bonaparte. Restoration, we call it, and it's a good name: it tried to make the armies as insulated from the population as they had been in 1648 (Mcneill 1984; Delbrück 1990; Ellis 1995).

Two centuries after Westphalia, the Spring of the Peoples of 1848 made clear that small groups of armed citizens could indeed challenge the power of the state, regardless of the continuing loyalty of the army. Haussman's broad avenues are the most visible part of the substantial reform, in this case concerned with the tactical environment of cities, needed to defeat the power to wage war of the people, as expressed in la barricade. We lack a broad name for it, but we know what it was all about - the long shadows of the Paris Commune and of the First International; the evolution of forms of representation, of democracy, of the welfare state (Tilly 1992).

Three centuries after 1648, the wars of decolonization on the wake of the Second World War showed how far small groups of people with guns could go. Small groups could wage, and hope to win, a war against the state. Much of the Cold War outside Europe had to do with the need to support, or repress, such small armed groups - bandits, guerrillas, insurrections, national liberation fronts, contra-revolutionaries, Mujahedeen: Ukraine, Greece, Vietnam, Algeria, Nicaragua, Afghanistan (Ellis 1995). 
Even smaller groups could and did wage war. Again, war in essence, the act of force to bend the will of others, not war juridically defined. The war of terrorists, which sought to bring about conditions in which its fight could hope to succeed, no matter how hopeless: the Irgun and the Stern Gang ${ }^{2}$; the IRA ${ }^{3}$ and the ETA $^{4}$; Marighella ${ }^{5}$ and the Brigate Rosse ${ }^{6}$; the $\mathrm{PLO}^{7}$ and Al-Qaeda ${ }^{8}$.

All this is undeniably war, and it reveals how baseless the assumptions of Westphalian International Law have become.

\section{Adapting to circumstances}

\footnotetext{
${ }^{2}$ Groups that were splinters from the paramilitary mainstream and served as the armed vanguard, and to a substantial extent the political and military leadership and cadres of the armed forces of groups trying to create a State of Israel in the 1930 s to the 1940 s. ${ }^{3}$ Group responsible for direct action in support of Irish claims for independence in the 1900s-1920s; also, but not to be confused with the Provisional Irish Republican Army, the splinter group that kept fighting for the incorporation of Northern Ireland ever since.

4 The Basque Separatist Army, that supports the claim for the independence of the Basque country from Spain since the $1940 \mathrm{~s}$.

5 Carlos Marighella, member of the Aliança Libertadora Nacional, a Brazilian group of the 1960 s and 1970 s that opposed the local military regime, and author of, among others, Minimanual de Guerrilha Urbana, arguably the founding text of contemporary "urban" terrorism. 6 An Italian group that operated in the 1960s and 1970s aiming at a socialist revolution in Italy through high profile "direct action".

7 The umbrella organization for the various Palestine groups that fought for the independence of Palestine, later the source of the political party of the same name in $\mathrm{Pal}$ estine.

${ }^{8}$ The organization - some would say a franchise - of Islamic groups nwhich share a fundamentalist, revolutionary agenda in various countries, in order to bring a New Caliphate that would unify the Islamic world in political terms, founded c. 1990.
}

The answer of Westphalian International Law to these ever-growing challenges became weaker and weaker as time passed. The loss of the state's exclusive ability to wage war and the growing power of small armed groups to do so were addressed with increasingly contradictory and ultimately unsatisfactory compromises until the present day.

On the one hand, there it was. Even condemning any wars by non-state actors as illegal, all non-state armed groups as criminal, one still had to deal with the fact that sometimes they achieved their goals. It was necessary to accept the faits accomplis - the American Republic, the French Republic and Empire, the long string of states that emerged, as Mao Dze Dong so aptly put it, from the barrel of a gun. And, although it will not be the case to address this here, that could only have come from the barrel of a gun (Ellis 1995; Delbrück 1990)

It was eventually of some political interest to admit the recognition of one or another of those groups, in some way, as potential or prospective states. This entailed the potential or prospective legality of their fight and of the fact that they were fighting. This still creates all the difficulties of two centuries ago. When do criminally armed people become potential, or prospective sovereign, legal states? How to tell legal combatants from illegal ones? Are guerrillas legal combatants? Are terrorists legal combatants? How to expect compliance to the law by those who it declares criminals? How to enforce the law to the benefit of those who flout them? How to hope to preserve the law among those who are put at a disadvantage when they do follow it? A law that refuses to take up the issues it faces is self-neglecting and leaves us at the mercy of the discretion of the mighty. A law that cannot be enforced is irrelevant. A law that is a liability only to those who would follow it is suicidal, besides being inherently unfair.

On the other hand, as much as possible these matters were deemed "internal". Swept under the rug, if you will, of sovereign domestic concerns. Each state could expect to have a free hand in using its resources to deal with the challenge of armed groups. Occasionally, another state would see some use in supporting those groups, or in supporting another state against some other groups. Nevertheless, this had to be done discreetly. Above all, it was important to preserve the right to wage war out of the hands of such groups, out of the hands of non-state actors. By considering whatever happened as an internal affair, then this legal fiction, divorced from reality in its essence, could still endure a while longer (Wawro 2000).

And it worked, after a fashion. It worked to the exact extent the resources available to such groups, or significant to such groups, could be found within the territories of the states they were fighting, or, occasionally, of their allies. This dovetailed, further, with the political goal of treating any such actions as criminal, denying legitimacy to those causes that they fought for, seeking to minimize the effects of the fight against them to the Rule of Law. Even if the Rule of Law was made fragile, bent or fractured in far too many occasions, often to the disapproval of allies who did not like the precedent or the consequences. 
${ }^{9}$ Bombings of US Embassies in Nairobi, Kenya and Dar Es Salaam, Tanzania, on $7 \mathrm{Au}-$ gust 1998.

${ }^{10}$ Bombing of the World Trade Center in New York, NY, on 26 February 1993. ${ }^{11}$ Hijacking of four commercial flights, two of which hit the Twin Towers of the World Trade Center building; one hit the Pentagon, in Washington D.C. and one was brought down by its passengers near Shanksville, Pennsylvania on 11 September 2001.
But again all this could happen because this was, and to the exact extent that this was, an internal matter (Neiberg 2003).

Alas, that is clearly no longer possible. Not after Kenya and Tanzania ${ }^{9}$; New York $^{10}$, Washington, and Pennsylvania ${ }^{11}$; Madrid ${ }^{12}$, Moscow ${ }^{13}$, and Beslan ${ }^{14}$. Westphalian International Law has reached the end of its rope; it can go no further.

We face the reality of small groups, which are internationally connected. They have resources in many different places, and act in yet other different places, across international boundaries. Groups that have the means to challenge the state. Let us agree that they can do so with varying degrees of expectation of success in their goals, or in their uses of force. Let us also agree that most will not achieve what they seek or succeed in all their actions. But let us recognize their undoubted ability to cause significant damage. And let us further agree that they will go on, regardless of what might be our estimates of their eventual success.

\section{Weapons of mass destruction}

${ }^{12}$ Bombings against the commuter trains of Madrid, Spain, on 11 March 2004.

${ }^{13}$ Seizure of Moscow Theater and its crowded audience as hostages on 23 October 2002. ers and children in Beslan, North Ossetia, on 1 September 2004. ${ }^{14}$ Seizure of a school, teach-

Furthermore, the reality of weapons of mass destruction - specifically, of nuclear weapons - means that these groups can indeed hope to do extensive, potentially fatal damage to any number of states. This possibility makes the current understanding of the legal requirements of self-defense, as expressed in Westphalian International Law, nothing short of suicidal. Is it reasonable to wait for the detonation of the first device before taking any action (Mcnaught 1984)?

In 1648 , it was reasonable to wait, to characterize self-defense after being attacked. A single blow could not be substantive, and in no case was potentially fatal or crippling. No single garrison or fortress, even if defeated or taken, was fatal to the prospects of a major power. Such a loss could be endured. This might not have been the case of smaller states. But lesser powers do not make International Law. So, by codifying self-defense after the blow, once again, International Law faithfully abided to the strategic reality of the age of kings. A reality that resulted from the tactical and logistical underpinnings of 1648. Its assumption was: the first blow could not be fatal, crippling, or unendurable. This is no longer the case.

\section{Theoretical considerations}

One and the other constitute a challenge to the very foundations of our current understanding of the basic elements of International Law. Not to the idea of International Law in itself, but the current fundamental underpinnings of its Westphalian version.

It is quite impossible to present an exhaustive list or even an exhaustive outline of what this entails. However, three issues do seem to present themselves as being both of pressing character and immediate utility for the new foundation of International Law.

War is a social and political phenomenon, with theoretical formulations that constraint alternatives and define relationships that transcend circumstances, while arguing for the importance of context (Clausewitz 1976). This must be taken into account before addressing it as a juridical matter. This fact must be the starting point of the consideration that wars are not fought only by states or against states. Wars are fought by actors who wish to obtain a better situation by force or by threatening its use; to obtain a given status quo they feel is more fa- 
vorable than the current or, at least, more favorable than what one's opponents are striving for. States are only one possible kind of actor among many others.

Which political actors should be legal users of force, or, alternatively, against which political actors should it be legal to use force? Under what conditions? That, then, seems to be the core of the matter. This entails the consideration of such matters as the requisites and procedures for declarations of war, treaties of peace and the such. This should not be mistaken for a challenge to the conception of sovereignty, but rather to the automatic association between state sovereignty and the use of force - either as an agent or as a target.

A related matter is how to treat those captured during a war - as expressed above - regardless of their status as legal combatants. The refusal to face the fact that wars might involve non-state belligerents creates a juridical vacuum. If one admits being at war with them, they ipso facto become entitled to prisoner-of-war rights and prerogatives; if these rights and prerogatives are granted to them, they become ipso facto legal combatants of acknowledged sovereignty, undermining the idea of the state's monopoly of war. But if these rights and prerogatives are not granted to them, then what kind of protections and guarantees will they have? Shall they have none? How to protect the innocent under these conditions? (Willmott 2002; Delbrück 2005)

To return to a point presented above, how to deal with self-defense? As matters stand today, this is exclusive of those attacked, after they are attacked or, in a twist or two, when it is clear that they have been all but attacked. Even this twist currently applies more readily to, say, individuals or ships than to states. A while ago, this requirement might still make some sense in what concerned major powers, though not to lesser ones. Nowadays, weapons of mass destruction, particularly nuclear weapons, have made this foolhardy if not actually suicidal as explained above. Waiting for the first strike has become prohibitive even to major powers, if a prospective opponent has or can have such weapons. If this fact is not taken into account in what concerns the discussion of what is self-defense, then those strong enough to do so will ignore the legality of their actions: they will act. If dying becomes the sole legal alternative then, soon enough, only the dead will be lawful. Legality will rank low in the decision making of the main actors in international politics. This does not seem a promising outcome for International Law.

\section{Contextual consequences: towards an agenda}

This is not "a US problem". This is not even a major-power problem. This is a problem for the entire world. It is our problem. There is no logical reason why any one country would be certain that it would never be the target or the site of a terrorist attack. The very integration of the world puts targets to any one terrorist group anywhere. What would be the results of a New York-like, or a Madrid-like, or a Beslan-like attack to just about any city, region or country in the world? What would be the consequences - to public opinion, to business opportunities, to life? How would one respond?

Strategic Studies was once described as thinking about the unthinkable. So think about a nuclear detonation just about anywhere. Now, wouldn't this be a catastrophe? Assuming we survived - and most of us would in this scenario wouldn't it bring changes to our world that we would rather avoid? Shouldn't we try to do something about it before it happens?

Second, this is not a US problem. It is not about yielding passively, or resisting futilely, to whatever might be the current proffered choice of the US administration. On the contrary. Doing nothing or pretending the problem does not exist, or conversely, assuming it is a US problem, is just about the only way to 
make sure we will be forced - by circumstances or by a fait accompli - to yield passively or resist futilely. This is about standing up and pitching in. This is about knowing the problem exists, being qualified and, hopefully, wise about alternatives; about being able to make one's weight felt and one's opinion count. This is about joining in the process of solving the problem, safeguarding our interests as much as we can.

Third, whatever choices we make we should have some things quite clear before us. This means work, commitment, and the allocation of resources that, if things were different, might go elsewhere. It entails the contemplation of disagreeable, occasionally terrifying, prospects. It means politics, give and take, negotiation, compromise, and coercion.

In other words, it means dealing with danger. Dealing with complexity, uncertainty, and change. Complexity, as this cannot be confined to a single discipline, to a single perspective, to a miraculous cure. Uncertainty, because there are no absolute certainties in this matter, and there will be precious few certainties as we begin. Change, because that is what stands before us. Recognition that change has gone beyond the reach of an adaptation of what we have now, what we are familiar with, and that puts us all in danger.

In consolation, dealing with complexity, uncertainty and change has been the motif of most of our lives, women and men of the $21^{\text {st }}$ Century. We all know the seductive pitfalls, and the terrible price, of ignoring any of them. We also know the rewards of learning to use them for our benefit. If it helps, think of it in terms of doing something that will directly affect the life and safety of those you love, because it does.

So there it is. We hope to have been able to explain why we think this is a critical, fundamental issue before us. Why the task at hand is the reformation of the structure of International Law that has been in place for three-and-a-half centuries. Not on a whim or a fad, or because it seems expedient to do so, but because the fundamental tactical, strategic and logistical realities that it sought to regulate have changed beyond its ability to cope.

We hope to have also been able to give enough detail so that no one thinks a solution will simply come out, like Athena from Zeus' brow, perfect, ready, mature, from some sort of mending and bending of the 'principles' of International Law that have been with us for the past 350 years. Those assumptions were only 'principles' in law, and they no longer hold water. In a switch from a famous remark, International Law is far too important to be abandoned to jurists.

Like any change that springs from new realities, the remaking of International Law will need study. Deep study - of tactical, logistical, strategic, political, social, philosophical, and legal issues - of current alternatives and of past foundations. There is at least as much to be sought in the past, when the assumptions now overcome did not apply, as from the present, when they have ceased to apply.

There is much to be found in a return to fundamental theorists. We do not refer to Aristotle or Smith, Hobbes or Marx, Weber or Machiavelli, Adams or Madison, Jefferson or Montesquieu or Clausewitz as giants because they were abnormally tall. Their work is the cornerstone of our ability to understand, and therefore to act with conscience. There is real need to redress our understanding on solid theoretical foundations, if for nothing else to shred the cobwebs of over three centuries from our minds.

This kind of deep study requires resources and time, efforts in both theory and application. But those seem to be the only reliable basis for action. Study 
and action will provoke discussion, and give content and basis to fruitful, enduring political decisions.

For all the inescapable need for study and practice, time and work, a little skepticism is also called for. Founding International Law anew will be a complex and protracted process. Barring a surprising and sudden consensus, it may take years or decades. On the one hand, this means that powerful actors will lose some of their present institutional power resources, the power that comes from the very framework which needs to be changed. Further, they will know in advance that they will lose power, and so they will stubbornly resist these changes as much as they can. On the other hand, this also means that as the current structure is abandoned, but before a new one takes its place, there might be a period of strict unlawfulness in international affairs.

This recognition should bring us a sense of urgency. The longer it takes for the intellectual and political debate to begin, the more protracted will be the period of unlawfulness. The longer unlawfulness lasts, the more the resulting new foundations of International Law will be suited to the political convenience of the major powers of the day, and the smaller will be the ability of others to shape the new juridical environment.

Unlawfulness means the arbitrary rule of the stronger. That is abhorrent to all those expectations of progress and the pursuit of happiness we feel and hope to be ours. But that should not blind us to the fact that strength exists, and that the strong can subvert juridical orders. That means that the new International Law will have to be acceptable to the strong. Otherwise, it will be irrelevant because the strong may choose not to abide by it. We must avoid falling prey to idealisms. Should law go against political reality, political reality will go against the law.

Further, refusing to face the task at hand will not preserve Westphalian International Law. Even if we tried to preserve its 'principles' as a sort of moralist deontology, it would still be helpless before reality. Any such a refusal will but mean that refounded International Law will come into being exclusively by the acts, deeds and choices of those who have the material - tactical, logistical, and strategic - means to impose their will upon others by force. But it cannot be preserved as it is: one way or the other, International Law will be made anew.

The material tactical, logistical, and strategic foundations of coercion upon which Westphalian International Law was erected have collapsed and are no more. International Law is no longer reasonable because it is no longer effective or useful. It cannot be amended any further within the Westphalian framework. The time has come to refound International Law.

\section{Post-scriptum}

This brief note outlines a more thematic perspective of the bibliography. The theoretical perspective is an application of Clausewitz (1976), with the benefit of Delbrück (1990; 2005). Arend \& Beck (1993), Koskenniemi (2004), Neff (2005), and Willmott (2002) contextualize the thrust of the text in what concerns the expectations of International Law. The historical reconstruction that provides the structure for the first part derives from the combination of Earle (1973), Ellis (1995), Knox and Murray (2001), Paret (1986), on one hand, and Anderson (1998), Neiberg (2003) and Wawro (2000), on the other. Gat (2008), McNeill (1984), and Tilly (1992) provide a connection between the historical reconstruction and the assessment of present capabilities supported by Alger (1985), Chant (1980), Dunnigan (2003), and McNaught (1984) that comprise the second part. 
Eugenio Diniz (eudiniz@ pucminas.br) is a D.Sc. in Production Engineering (Strategic Studies), Federal University of Rio de Janeiro, and Professor at the Pontifícia Universidade Católica do Rio de Janeiro (PUC-RJ).

Domício Proença Júnior (domicio@ @entroin.com.br) is a D.Sc. in Engineering (Strategic Studies), Federal University of Rio de Janeiro, and Professor at the same university.

\section{References}

Anderson, M.S. 1998. War and Society in Europe of the Old Regime 1618-1789. Montreal: McGill-Queen's University Press.

Alger, J.I. 1985. Definitions and Doctrine of the Military Art: Past and Present. London: Avery Publishing Group.

Arend, A.C.; Beck, R. 1993. International Law and the Use of Force: beyond the U.N. Charter Paradigm. New York: Routledge.

Chant, C. 1980. How Weapons Work. New York: Marshall Cavendish.

Clausewitz, C. 1976. On War. Princeton: Princeton University Press.

Delbrück, H. 1990. History of the Art of War. 4 vols. Lincoln: University of Nebraska Press. 2005. Delbrück's Modern Military History. Lincoln: University of Nebraska Press.

Dunnigan, J.F. 2003. How to Make War: A comprehensive Guide to modern Warfare in the Twenty-First Century. $4^{\text {th }}$ ed. New York: Harper Paperbacks.

Earle, E.M., ed. 1973. Makers of modern Strategy: Military Thought from Machiavelli to Hitler. Princeton: Princeton University Press.

Ellis, J. 1995. From the Barrel of a Gun: A History of Guerrilla, Revolutionary and Counter-Insurgency Warfare, from the Romans to the Present. London: Greenhill Books.

Gat, A. 2008. War in Human Civilization. Oxford: Oxford University Press.

Knox, M.; Murray, W., eds. 2001. The Dynamics of Military Revolutions, 1300-2050. Cambridge, UK: Cambridge University Press.

Koskenniemi, M. 2004. The gentle Civilizer of Nations: The Rise and Fall of International Law 1870-1960. Cambridge, UK: Cambridge University Press.

Mcnaught, L.W. 1984. Nuclear Weapons and Their Effects. Sterling: Potomac Books.

Mcneill, W. 1984. The Pursuit of Power: Technology, Armed Force, and Society since A.D. 1000. Chicago: University Of Chicago Press.

Neff, S.C. 2005. War and the Law of Nations: A general History. Cambridge, UK: Cambridge University Press.

Neiberg, M.S. 2003. Warfare and Society in Europe: 1898 to the Present. London: Routledge.

Paret, P., ed. 1986. Makers of modern Strategy from Machiavelli to the Nuclear Age. Princeton: Princeton University Press. Tilly, C. 1992. Coercion, Capital and European States: AD 990-1992. Hoboken: Willey.

Wawro, G. 2000. Warfare and Society in Europe, 1792-1914. London: Routledge.

Willmott, H.P. 2002. When Men lost Faith in Reason: Reflections on War and Society in the Twentieth Century. Westport: Praeger.

\section{Resumo}

O artigo é um diagnóstico que expressa o colapso dos fundamentos materiais da capacidade coercitiva, ou seja, dos rígidos constrangimentos que se impõem a qualquer esforço político de reforma do arranjo regulatório internacional. O assunto é tratado no contexto geral associado ao Direito Internacional derivado do Tratado de Westfália, bem como de seus desdobramentos. A evolução do Direito Internacional é discutida a partir da perspectiva dos Estudos Estratégicos, de modo a demonstrar que a ordem Westfaliana era consistente com as realidades estratégicas, táticas e logísticas então vigentes. Em seguida, mostra-se como tais realidades subjacentes se transformaram. O contraste entre o Direito Internacional tal como estabelecido atualmente e as realidades estratégicas, táticas e logísticas hoje vigentes explicita a inconsistência entre ambos, o que é uma situação insustentável. Caso essas inconsistências não sejam diretamente confrontadas por um esforço de reflexão sustentado, tende-se a perpetuar uma situação em que o Direito Internacional será redefinido exclusivamente pelas decisões dos mais poderosos e pelas imposições arbitrárias dos mais fortes.

PALAVRAS-CHAVE: estudos estratégicos; teoria da guerra; Direito Internacional; teoria das relações internacionais; contexto internacional e estratégico atual.

License information: This is an open-access article distributed under the terms of the Creative Commons Attribution License, which permits unrestricted use, distribution, and reproduction in any medium, provided the original work is properly cited. 